\title{
The Parent Firms' Reverse Spillovers of China's Production-Oriented OFDI Enterprises: Evidence from Chinese Manufacturing Enterprises
}

\author{
Xueliang Yang \\ Jinan University, Guangzhou, China \\ Email: 1182879149@qq.com
}

How to cite this paper: Yang, X.L. (2017) The Parent Firms' Reverse Spillovers of China's Production-Oriented OFDI Enterprises: Evidence from Chinese Manufacturing Enterprises. Modern Economy, 8, 507-517.

https://doi.org/10.4236/me.2017.84038

Received: February 20, 2017

Accepted: April 10, 2017

Published: April 13, 2017

Copyright $\odot 2017$ by author and Scientific Research Publishing Inc. This work is licensed under the Creative Commons Attribution International License (CC BY 4.0).

http://creativecommons.org/licenses/by/4.0/ (c) $\underset{\mathrm{EY}}{\text { (i) Open Access }}$

\begin{abstract}
In recent years, the rise of Chinese investments follows the provisions of the "Going Out" strategy. Whether this local production foreign direct investment has a positive role in reverse spillovers to the parent company? Does the theme of the "Industry hollow" which has been caused great attention really existence? In this paper, we analyzed the reverse spillover of local production outward foreign direct investment (OFDI) using firm-level data from Chinese industrial enterprises in the period of 2000 to 2011 . We will separately analyze the problem from productivity, exports and the scale of production. Combining with the method of propensity score matching and difference in difference estimator, we find that the productivity, the scale of production, and the export have all significantly improved no matter which data sample we use. In general, the local production of OFDI has a positive effect on the parent company; the Chinese government should encourage the enterprises to go out.
\end{abstract}

\section{Keywords}

Local Production Outward Foreign Direct Investment, The Parent Firms' Reverse Spillover, Propensity Score Matching, DID

\section{Introduction}

China's Outward Foreign Direct Investment, which referred to as "OFDI" has made remarkable achievements in recent years. With the implementation of the strategy of "going out" and "the Belt and Road" initiative, China's outward foreign direct investment problems have drawn great attention in the academic circle. According to the 2015 statistics bulletin of the foreign direct investment in 
China, by the end of 2015 , the global foreign direct investment flow is $\$ 1.47$ trillion, China's foreign direct investment flow set a new record of $\$ 145.67$ billion, which has grown $18.3 \%$ compare with a year ago, becoming the world's second largest foreign investor. There are 20,200 Chinese companies have established 30,800 subsidiary corporations in 188 countries (regions); The Net foreign direct investment in China has reached \$1.09786 trillion, maintain the eighth in the world wide. The main purpose of the paper is to research The Parent Firms' Reverse Spillovers of China's Production-oriented OFDI Enterprises from the perspective of a more microscopic, and then mathematical proof the necessity of implementation of the strategy of "going out". As we all know, when a company investment outward, the TFP and export of parent firm will be effected by the action, we define the effect as backward spillover effect.

According to the division standard of china's ministry of commerce, outward foreign direct investment in China can be divided into commercial service, local production, technology research and resource exploitation by investment motive. Local production OFDI is refer to the foreign direct investment in host countries which have local production in there, is a form of the markets for foreign direct investment. Local production OFDI produced products in host countries, so need fixed capital investment and hiring foreign employees, and obviously different from other three categories. The main aim of the local production OFDI is in order to occupy the foreign markets and growing the company scale; by using foreign preferential policies and human resources to promote parent company's innovation ability and technical level of our country. With the rapid development of economy in our country, this kind of investment has gradually been paid much attention. So the Local production OFDI how to influence the effects of the parent company? We will analyze the problem in the following three aspects, which are productivity, export, and enterprise scale.

In regard to the mechanism of parent company's productivity to local production OFDI, we can conclude as the following three aspects. First, when we enter the foreign market, compare with the scale expanding, the profits raised too. The part of surplus profit will assigned to the parent company to research and development new technique. And then the Productivity level of parent company will be promoted. Second, this kind of investment can absorb excellent local human capital and advanced management experience to improve enterprise productivity. Because the local production OFDI enterprises will build plant in host countries, and hire local human capital, which is beneficial to the overseas branch of learning more advanced management experience and improve its research and development capabilities. The advanced management experience and research and development technology will feedback to parent company. Third, because of surplus capacity in domestic market, local production OFDI can expand the size of the market, and release the parent company's spare capacity, which would reduce the average cost of the parent company, and then raising the level of productivity in the parent company.

The relationship between the local production OFDI and export depends on 
trade form. If the local production OFDI will increase the parent company's equipment, raw materials and other supplies export, we can say that the local production OFDI can promote the export of the parent company. And if the local production OFDI in foreign produce the same kind of products as parent company, which will cause extrusion for the export of the parent company. In addition, the effect of the third party will affect parent company's export, too. All in all, the relationship between local production OFDI and export depends on the trade form.

As for the relationship between local production OFDI and the enterprise scale, we can draw a conclusion that the local production OFDI has a positive influence to parent company's scale according to previous research results. The reason of this conclusion is maybe the produce in host country need the middle of the products and raw materials which from parent company, and then results in economies of scale. Besides, carry through foreign direct investment, the subsidiary corporation can obtain more super profits, part of the profits will go to the parent company, which will expand the scale of its assets. Besides fixed cost or the flow of information sharing or other factors, such as learning effects can also cause the parent company scale up.

The remainder of this paper is composed of four sections: In section 2 we Do the literature review from two aspects of domestic and foreign; In section 3 we elaborate the model and characterize its equilibrium, and then report the resource of the data; The fourth part is the empirical test and result analysis; The fifth part is the conclusions of the paper.

\section{Literature Review}

The parent company's effect of OFDI is refer to the advance technology, resources, human resources, management experiences of foreign backward influence parent company's productivity, export, and the enterprise scale through foreign direct investment. The past research mostly concentrated with developed countries, and have not unified conclusion till now. Helpman, Melitz \& Yeaple [1] find that typical multinational enterprises with foreign investment have higher productivity than no foreign investment enterprises, but when referring to the personnel hiring and corporate profitability have no so significant effect. After that, according to Barba Navaretti et al. [2]; Desai, Foley \& Hines [3], we can conclude that either the FDI in horizontal or the FDI in vertical has a positive impact on productivity and the size of the parent company. When it comes to developing country, the correlative research have fallen a great deal. Ramamurti.R [4] argue that different from the traditional FDI enterprises, the main purpose of the enterprise of foreign investment in emerging economies is to obtain new competitive advantage or obtain scarce strategic materials. Luo and Tung [5] agree this viewpoint, they find that in developing countries, many enterprises start to invest outward is based on the strategic consideration, and thus to expand their scale as a whole. Based on Hijzen et al. [6], market seeking FDI will lead to the parent company and subsidiaries of the scale of production to 
expand at the same time, the reason maybe the Shared fixed costs or the flow of information or the learning effects. Herzer, [7], Desai et al. [3] find that home country and host country's productivity and competitiveness will also strengthen when subsidiary corporation need import equipment, intermediate product or raw material from parent company.

Domestic research on related issues also achieved fruitful results. Chang et al. [8] use the data from large state-owned enterprises in China found that the enterprise which invest outward has a significant influence to parent enterprise's technology innovation performance. Yu et al. [9] using panel data from 2003 to 2010 to research of foreign direct investment how to affect domestic labor productivity in the short term and long term effect. The result indicates that foreign direct investment does not affect the domestic labor productivity in the short term, but there is significant positive influence when it comes to long term. Jiang et al. [10] use china's industrial enterprises data from 2005 to 2008 find that technology research and development of outward FDI has a positive impact on their productivity. When it comes to "exports effect", Wu [11], Xie and Liu [12], Zhang [13] have researched the problem from the perspective of macro data. Jiang et al. [14] study the problem from the perspective of micro data. They use 1498 firms' data which come from China Industry Business Performance Data across 2005 to 2007 and find that the foreign direct investment from Chinese companies generally promote the parent enterprises to export, and the present " $U$ " type which first rise after falling.

To sum up, the research about backward spillover effect of foreign direct investment have obtained some achievements both at home and abroad, but there the empirical research from micro perspective still not enough. In the existing literature, most scholars use macroeconomic time series data or provincial panel data or industry data to research, rarely consider the enterprise heterogeneity, and ignore the enterprise's "self-selection effect". Besides, academic has not reach a consistent conclusion about backward spillover effect of China's foreign direct investment because of the different sample and its estimation method. In this article we try to use a more detailed data and rigorous identification methods to study on this issue, hoping to turn the empirical study into the theoretical research achievements, and then increasing the persuasive. At the same time, we hoping the results of the study can provide the reality basis for theoretical innovation, so as to improve the related theory.

\section{Model}

\subsection{Specification of Model}

As is well-known, because of "self-selection effect" about FDI and export, it is necessary to match a control group enterprise to eliminate the "self-selection effect". We refer to Girma et al., Greenway et al. to Preliminary processing data. In this paper we tend to choose Propensity score matching to match control group. We use the data a year before enterprise invest outward to match.

In this paper, we define outward direct investment of enterprises as the expe- 
rimental group, and the enterprises never invest outward as the control group. We use ofdii to representative the foreign direct investment by enterprise, assuming ofdi $i_{i}=1$ if the enterprise attend foreign direct investment, on the contrary, if ofdi $_{i}=0$ the enterprises have never invest outward. We define dt as foreign direct investment successively, we assume $\mathrm{d} t=1$ on behalf of after the foreign direct investment and $\mathrm{d} t=0$ means period before the foreign direct investment. Assuming $y_{i t}$ representative parent company's productivity, export, enterprise scale. And then the $\Delta y_{i}$ means the variation of "parent company effect". We use $\theta$ representative the effect of the parent company. Then we can draw the Equation (1).

$$
\theta=E\left(\theta_{i} \mid \operatorname{ofdi}_{i}=\right) 1=E\left(\Delta y_{i}^{1} \mid \operatorname{ofdi}_{i}=1\right)-E\left(\Delta y_{i}^{0} \mid \operatorname{ofdi}_{i}=1\right)
$$

Actually, $E\left(\Delta y_{i}^{0} \mid \operatorname{ofdi}_{i}=1\right)$ in Equation (1) can not estimate, because once a firm have already carry on OFDI, the data before OFDI can not obtain. Thus, we need match appropriate control group which is similar with experimental group to replace the data before OFDI. That is to say we should replace $E\left(\Delta y_{i}^{0} \mid \operatorname{ofdi}_{i}=1\right)$ with $E\left(\Delta y_{i}^{0} \mid \operatorname{ofdi}_{i}=0\right)$.we can transform Equation (1) to Equation (2).

$$
\theta=E\left(\theta_{i} \mid \operatorname{ofdi}_{i}=1\right)=E\left(\Delta y_{i}^{1} \mid \operatorname{ofdi}_{i}=1\right)-E\left(\Delta y_{i}^{0} \mid \operatorname{ofdi}_{i}=0\right)
$$

Equation (2) can representative the difference between experimental group and the control group. If $\theta>0$, show that OFDI have positive spillover effect. to the parent company. According to the principle, we design the following model:

$$
y_{i t}=a_{o}+a_{1} \cdot \text { ofdi }_{i}+a_{2} \cdot d_{t}+\theta \cdot \text { ofdi }_{i} \times d_{t}+\mu_{i t}
$$

According to Equation (3), we can calculate the changes of experimental group in OFDI successively, that is $\left(a_{0}+a_{1}+a_{2}+\theta\right)-\left(a_{0}+a_{1}\right)=a_{2}+\theta$. And the change of control group is $\left(a_{0}+a_{2}\right)-a_{0}=a_{2}$. We drag the result to Equation (2), we can draw that:

$$
\theta=E\left(\theta_{i} \mid \operatorname{ofdi}_{i}=1\right)=E\left(\Delta y_{i}^{1} \mid \operatorname{ofdi}_{i}=1\right)-E\left(\Delta y_{i}^{0} \mid \operatorname{ofdi}_{i}=0\right)=\left(a_{2}+\theta\right)-a_{2}=\theta
$$

So the interactive coefficient $\theta$ Is the effect of the parent company to OFDI.

Based on Equation (3), we Add the control variables and fixed effects, then we can draw Equation (4):

$$
y_{i t}=a_{t}+\delta_{k}+\gamma_{j}+\theta \cdot \text { ofdi }_{i j k l}+\lambda \operatorname{con}_{i j k l}+\mu_{i j k l}
$$

where $y_{i t}$ indicate parent company's effect, in this paper, we define them as productivity, export and firm scale. $a_{t}, \delta_{k}$ and $\gamma_{j}$ are year, region and industry effects, respectively.

\subsection{Variable Declaration}

In this paper, we choose the method of Levinsohn \& Petrin (LP) [15] to estimate the total factor productivity. The principle design as follow:

$$
v a_{i t}=\partial L_{i t}+\varphi\left(K_{i t}, M_{i t}\right)+\eta_{i t}
$$


where $v a_{i t}$ indicate industrial added value, $\mathrm{L}, \mathrm{K}$ and $\mathrm{M}$ are labor input, capital stock and Intermediate input, respectively. $\varphi\left(K_{i t}, M_{i t}\right)$ is the third order polynomial function approximation function. According to Equation (5), we can estimate the coefficient of labor and capital, and then we can calculate the TFP via Equation (6):

$$
\widehat{T F P}=v a_{i t}-\hat{\partial} L_{i t}-\hat{\alpha} K_{i t}
$$

We use per capita fixed assets of industrial enterprises to replace the capital intensity; and use average annual workers to replace enterprise scale.; Value of Export Delivery indicate whether the firm export. If the value of Export Delivery greater than 0 , we assignment the variable to 1 , others equal to 0 . If the capital is from foreign, with Hong Kong, Macao and Taiwan, we assignment 1 to wzjr, otherwise 0. we assignment all provinces except Beijing is 0, Beijing area is 1 to representative region effect; Industry virtual variables, we take the technology intensity of higher general equipment manufacturing, such as transportation equipment manufacturing, electrical machine equipment manufacturing, computer and other electronic equipment manufacturing as a benchmark, assign a value to 1 , otherwise 0 . The main variables of descriptive statistics are shown in Table 1.

\subsection{Data Source}

In the article, we use the data from Chinese industrial enterprises statistical database across 2000 to 2011, combine with the list of foreign investment enterprises from ministry commerce of china. And then matching the two database to obtain foreign investment enterprises in the industrial enterprise database in various financial indicators. First, we selected local manufacturing OFDI firms from the list of foreign investment enterprises. Second, we merge the database with Chinese industrial enterprises statistical database, eventually, we found 544 foreign direct investment firms which have local production OFDI. Specific matching results are shown in Table 2 (2000-2007).

\subsection{Propensity Score Matching Method}

As a result of self-selection effect about total factor productivity, in this paper, we tend to select score matching method to choose the suitable control group enterprise to elect the influence of the self-selection effect, and at the same time

Table 1. Descriptive statistics.

\begin{tabular}{ccccc}
\hline variable & Mean & Std & Min & Max \\
\hline TFP & 7.270 & 2.780 & -7.630 & 18.81 \\
Lgcapital & 3.740 & 1.450 & -7.420 & 15.45 \\
Lgexport & 9.430 & 1.850 & -0.690 & 19.04 \\
lgemploy & 4.730 & 1.120 & 0.569 & 12.29 \\
Lg(total value) & 10.16 & 1.460 & 0 & 19.17 \\
\hline
\end{tabular}

Source: China Industry Business Performance Data. 
Table 2. Local production OFDI matching result.

\begin{tabular}{cccccccccc}
\hline year & 2000 & 2001 & 2002 & 2003 & 2004 & 2005 & 2006 & 2007 & sum \\
\hline OFDI Firm & 30 & 19 & 79 & 87 & 203 & 1138 & 1501 & 1730 & 4787 \\
Local Production OFDI & 4 & 3 & 13 & 17 & 51 & 207 & 231 & 247 & 773 \\
matching result & 1 & 1 & 1 & 3 & 8 & 51 & 55 & 71 & 191 \\
\hline
\end{tabular}

Source: China Industry Business Performance Data and The Ministry of Commerce List of foreign investment enterprises.

Table 3. Experimental group and control group amount.

\begin{tabular}{cccc}
\hline & experimental group & control group & matching \\
\hline Productivity effect & 1771 & $2,135,132$ & 1652 \\
Export effect & 1757 & $2,037,294$ & 1756 \\
Scale effect & 1208 & $1,240,797$ & 1208 \\
\hline
\end{tabular}

Source: The author calculate.

reduces the data selection bias. According the research of Caliendo and Kopeinig, there are two steps of Propensity score matching method. First, select the appropriate variables, using the Probit (or Logit) model estimation pscore. In this paper, we select the Logit model, and select the density of capital, the characteristics of enterprise ownership, enterprise scale a year before OFDI, and the industry and region as attribute variables. The principle is like follow equation:

$$
\operatorname{Logit}\left(\operatorname{ofdi}_{i t}=1\right)=\phi\left(h\left(x_{i(t-1)}\right)\right)
$$

Second, according to the estimate $\mathrm{p}$ score in step one, we match the experimental group with control group, this paper adopts the tendency of 1:1 score matching. Specific matching results are shown in Table 3.

\section{Results}

In the article, we analysis different parent effects respectively, and we do the empirical analysis by means of stata, a Econometric analysis software, which has been widely applied to academic research.

\subsection{The Results of "Productivity Effect"}

Table 4 present the results of "Productivity effect". Column 1 present the benchmark test which has not join any control variable and fixed effects. From the sign of the coefficient OFDI, we can draw the conclusion that parent production OFDI has a significant positive effect on TFP. That is to say parent production OFDI significantly promoted the parent company's productivity improvement. But is the conclusion robust? We need further verification. Column 2 present the results which add capital density, export and other control variables. Even the coefficient of OFDI decreases, but the conclusion remains robust. Column 3, Column 4 and Column 5 have joined year effects, region effects and industry effects, respectively. we find that the coefficient is gradually decline, but 
Table 4. "Productivity effect" results.

\begin{tabular}{|c|c|c|c|c|c|}
\hline & (1) tfp & (2) tfp & (3) $\mathrm{tfp}$ & (4) tfp & (5) tfp \\
\hline ofdi & $2.775^{\star * \star}(21.16)$ & $1.768^{\star * *}(7.63)$ & $0.822^{\star * *}(8.32)$ & $0.786^{\star * *}(7.95)$ & $0.784^{\star * *}(7.84)$ \\
\hline Capital density & & $0.000152^{\star}(2.02)$ & $0.000108^{\star * *}(3.69)$ & $0.000107^{\star * \star}(3.66)$ & $0.000107^{\star * \star}(3.66)$ \\
\hline export & & $0.102(0.66)$ & $0.156^{\star * *}(3.40)$ & $0.162^{\star * *}(3.54)$ & $0.161^{\star * *}(3.54)$ \\
\hline scale & & $-1.480^{\star * *}(-10.77)$ & $-0.937^{\star * *}(-16.08)$ & $-0.924^{\star * \star}(-15.91)$ & $-0.924^{\star * *}(-15.88)$ \\
\hline Foreign capital & & $0.805^{\star * *}(5.30)$ & $0.114^{*}(2.26)$ & $0.119^{*}(2.38)$ & $0.119^{*}(2.38)$ \\
\hline Year effects & No & No & Yes & Yes & Yes \\
\hline Region effects & No & No & No & Yes & Yes \\
\hline Industry effects & No & No & No & No & Yes \\
\hline _cons & $8.226^{\star * *}(97.62)$ & $12.33^{\star * \star}(27.21)$ & $6.763^{\star * \star}(29.16)$ & $6.727^{\star * \star}(29.14)$ & $6.727^{* * *}(29.11)$ \\
\hline $\mathrm{N}$ & 3422 & 3422 & 3422 & 3422 & 3422 \\
\hline
\end{tabular}

$\mathrm{t}$ statistics in parentheses

${ }^{*} \mathrm{p}<0.1 ;{ }^{* *} \mathrm{p}<0.05 ;{ }^{* *} \mathrm{p}<0.01$

Source: The author calculate.

the conclusion remains robust. The results suggest that the local production OFDI have a positive impact on productivity of parent company, and robust. The result is consistent with the traditional research. And the only difference is that we draw the conclusion from a more microcosmic angle.

From the perspective of the test results of control variables, the capital density, exports, as well as whether there is a foreign capital, the coefficients are all significantly positive. But the enterprise scale coefficient significantly negative. It is not difficult to understand the coefficient of capital density is positive. Because the higher density of capital may need machine equipment and the higher technical level. The coefficient of export is significantly positive conform to the traditional theory expected. According to traditional research, the export enterprises can contact with foreign advanced technology and management level easier, and then promote the technology level of the parent company through learn effect. The coefficient of foreign capital significant decline after join the control variables, but still significantly positive. The enterprise with foreign capital participation has internationalization view and easier to contact advanced technology which is advantageous to the parent enterprise technology innovation. The enterprise scale coefficient is negative and significant. This means that the local manufacturing OFDI enterprise scale and the level of productivity is negative correlation. This may be associated with local production OFDI enterprise's own characteristic, the bigger scale is not easy to change and adjustment, it is the smaller one adjust up quickly, in order to obtain excess profit has motivation to technical innovation.

\subsection{The Results of "Export Effect"}

Table 5 present the results of "Export effect". It can be seen that even the coeffi- 
Table 5. "Export effect" results.

\begin{tabular}{|c|c|c|c|c|c|}
\hline & (1) export & (2) export & (3) export & (4) export & (5) export \\
\hline ofdi & $0.469^{* * *}(26.83)$ & $0.338^{\star * \star}(13.11)$ & $0.303^{\star * \star}(10.75)$ & $0.303^{\star * \star}(10.74)$ & $0.297^{\star * \star}(10.27)$ \\
\hline Capital density & & $-0.00000364(-0.41)$ & $-0.0000177(-1.91)$ & $-0.0000178(-1.92)$ & $-0.0000180(-1.94)$ \\
\hline $\mathrm{tfp}$ & & $0.00202(0.84)$ & $0.0365^{\star \star \star}(4.57)$ & $0.0369^{\star * \star}(4.60)$ & $0.0373^{\star \star \star}(4.64)$ \\
\hline scale & & $-0.148^{\star * *}(-8.09)$ & $-0.0970^{\star * *}(-4.59)$ & $-0.0966^{\star * *}(-4.57)$ & $-0.0953^{* * *}(-4.50)$ \\
\hline Foreign capital & & $0.113^{* * *}(9.40)$ & $0.190^{\star * *}(12.19)$ & $0.190^{\star * *}(12.16)$ & $0.190^{\star * *}(12.19)$ \\
\hline Year effects & No & No & Yes & Yes & Yes \\
\hline Region effects & No & No & No & Yes & Yes \\
\hline Industry effects & No & No & No & No & Yes \\
\hline _cons & $0.116^{* * *}(12.52)$ & $0.533^{* * *}(9.28)$ & $0.250^{\star *}(2.99)$ & $0.248^{\star \star}(2.96)$ & $0.242^{\star \star}(2.87)$ \\
\hline $\mathrm{N}$ & 3512 & 3512 & 3512 & 3512 & 3512 \\
\hline
\end{tabular}

$\mathrm{t}$ statistics in parentheses

${ }^{\star} \mathrm{p}<0.1 ;{ }^{* *} \mathrm{p}<0.05 ;{ }^{* *} \mathrm{p}<0.01$

Source: The author calculate.

cient gradually decline after add the control variable and fixed effects, but the influence of local production OFDI to exports are still highly significantly positive. That's to say the local manufacturing OFDI is advantageous to the parent company's export. The verdicts are consistent with Jiang [14]. Blonigen argues that the local manufacturing OFDI affected the export of the parent company mainly depends on the trade form of enterprise. Combining with the condition of our country, the enterprises of our country are the type of subsidiary in most cases, the products produced in host country are generally need to import intermediate products from the parent company, therefore, our country local production OFDI has positively influence to parent company's export.

\subsection{The Results of "Scale Effect"}

Table 6 present the results of "Scale effect". We use the gross industrial output value to represent enterprise scale. According to the inspection results, we find that the coefficient of OFDI symbol is not steady, when no join control variables, coefficient is positive, that is the local production OFDI is conducive to the expansion of enterprise scale. When we join the control variable, symbol becomes negative, and still significant. After join the fixed effects, symbols switch to positive. In general, local production OFDI has positive impact on parent company's scale. We can draw the conclusion may be based on two reasons. On one hand, the company outward expansion is bound to increase the company's gross industrial output value and expand the scale of the company; on the other hand, local production OFDI need import raw materials or intermediate products from parent company which will expand the scale of production, and increase the gross value of industrial output. 
Table 6. "Scale effect" results.

\begin{tabular}{|c|c|c|c|c|c|}
\hline & (1) Tolal value & (2) Tolal value & (3) Tolal value & (4) Tolal value & (5) Tolal value \\
\hline ofdi & $4.890^{* * *}(58.21)$ & $-2.713^{* * *}(-12.63)$ & $1.324^{* * *}(5.35)$ & $1.324^{* * *}(5.35)$ & $1.324^{* * *}(5.35)$ \\
\hline Capital density & & $-0.000180^{* * *}(-6.67)$ & $-0.0000109(-0.42)$ & $-0.0000110(-0.43)$ & $-0.00000873(-0.34)$ \\
\hline $\mathrm{tfp}$ & & $0.814^{\star \star \star}(35.80)$ & $1.064^{\star * \star}(43.94)$ & $1.064^{\star * \star}(43.91)$ & $1.066^{\star * \star}(43.97)$ \\
\hline export & & $0.0886(1.12)$ & $0.0611(0.87)$ & $0.0613(0.88)$ & $0.0587(0.84)$ \\
\hline Foreign capital & & $0.0801(1.94)$ & $0.219^{* * *}(4.11)$ & $0.219^{\star * \star}(4.11)$ & $0.225^{\star \star \star}(4.20)$ \\
\hline Year effects & No & No & Yes & Yes & Yes \\
\hline Region effects & No & No & No & Yes & Yes \\
\hline Industry effects & No & No & No & No & Yes \\
\hline _cons & $7.097^{* * *}(146.88)$ & $5.045^{\star \star \star}(77.13)$ & $4.332^{\star \star \star}(57.74)$ & $4.332^{\star \star \star}(57.72)$ & $4.313^{\star \star \star}(56.81)$ \\
\hline$N$ & 2387 & 2387 & 2387 & 2387 & 2387 \\
\hline
\end{tabular}

$\mathrm{t}$ statistics in parentheses

${ }^{*} \mathrm{p}<0.1 ;{ }^{* *} \mathrm{p}<0.05 ;{ }^{* *} \mathrm{p}<0.01$

Source: The author calculate.

\section{Conclusion}

The backward spillover effect of OFDI is an international hotspot issues, especially along with "the Belt and Road" initiative, we focus on the hot issues, and try to certify the necessity of the policy implementation through empirical analysis. We selected the industrial enterprise database data from 2000-2011, and connecting with the list of foreign investment. We match the control group which is similar to experimental group through PSM method. And then we use the method of DID to inspection, getting the following conclusion: 1) Local production OFDI enterprises have significantly higher productivity than before investment. That's to say, local production OFDI promotes the increase of its parent company's productivity. 2) Local production OFDI has a positive impact on parent company export, local production OFDI promote the export of the parent company. 3) Local production OFDI has a positive "scale effect" to the parent company. The scale of parent company will expand when the company investment outward. The deficiency of the article is that there are not enough data from local production OFDI enterprises, especially, the data of recent years are not available. The further research of the question is worth waiting for and necessary.

\section{References}

[1] Helpman, E., Melitz, M. and Yeaple, S. (2004) Export versus FDI with Heterogeneous Firms. American Economic Review, 94, 300-316. https://doi.org/10.1257/000282804322970814

[2] Barba Navaretti, G., Castellani, D. and Disdier, A.C. (2010) How Does Investing in Cheap Labour Countries Affect Performance at Home? Firm-Level Evidence from 
France and Italy. Oxford Economic Papers, 62, 234-260. https://doi.org/10.1093/oep/gpp010

[3] Desai, M.A., Foley, C.F. and Hines, J.R. (2009) Domestic Effects of the Foreign Activities of US Multinationals. American Economic Journal: Economic Policy, 1, 181 203. https://doi.org/10.1257/pol.1.1.181

[4] Ramamurti, R. (2012) What Is Really Different about Emerging Market Multinationals? Global Strategy Journal, 2, 41-47. https://doi.org/10.1002/gsj.1025

[5] Luo, Y. and Tung, L.R. (2007) International Expansion of Emerging Market Enterprises: A Springboard Perspective. Journal of International Business Studies, 38, 481-498. https://doi.org/10.1057/palgrave.jibs.8400275

[6] Hijzen, A., Jean, S. and Mayer, T. (2011) The Effects at Home of Initiating Production Abroad: Evidence from Matched French Firms. Review of World Economics, 147, 457-483. https://doi.org/10.1007/s10290-011-0094-x

[7] Herzer, D. (2012) Outward FDI, Total Factor Productivity and Domestic Output: Evidence from Germany. International Economic Journal, 26, 155-174.

https://doi.org/10.1080/10168737.2010.538430

[8] Chang, Y. (2011) The Reverse Technology Spillovers China's Foreign Direct Investment-Evidence from Large State-Owned Enterprises of China. Economic Management, 1, 9-15.

[9] Yu, G.S. and Wang, W.Y. (2013) The Relationship of Investment Outward, Economic Development and Domestic Employment Skill Structure-Theoretical Mechanism and Empirical Study Based on China's Data. International Trade Issues, 6 , 135-144.

[10] Jiang, G.H., et al. (2013) "Productivity Effect” of China's Technology Research and Development FDI-Evidence from Industrial Enterprises. Management of the World, 9, 44-54.

[11] Xiang, B.W. (2009) Research on the Trade Effect of China's Foreign Direct Investment-Cointegration Analysis Based on Panel Data. Finance and Economics, 4, 77-82.

[12] Xie, J. and Liu, R.Y. (2011) Study on the Influencing Factors and Trade Effects of China's Foreign Direct Investment Based on Spatial Perspective. International Trade Issues, 6, 66-74.

[13] Zhang, J.G. and Kang, H. (2012) The Research of China's Foreign Direct Investment Trade Effect. Quantitative Economic Technology and Economic Research, 6, 74-85.

[14] Jiang, G.H. and Jiang, D.C. (2014) "Export Effect” of Chinese Enterprises' Foreign Direct Investment. Economic Research, 5, 160-173.

[15] Levinsohn, J. and Petrin A. (2003) Estimating Production Functions Using Inputs to Control for Unobservables. Review of Economic Studies, 70, 317-341. https://doi.org/10.1111/1467-937X.00246 
Submit or recommend next manuscript to SCIRP and we will provide best service for you:

Accepting pre-submission inquiries through Email, Facebook, LinkedIn, Twitter, etc. A wide selection of journals (inclusive of 9 subjects, more than 200 journals)

Providing 24-hour high-quality service

User-friendly online submission system

Fair and swift peer-review system

Efficient typesetting and proofreading procedure

Display of the result of downloads and visits, as well as the number of cited articles Maximum dissemination of your research work

Submit your manuscript at: http://papersubmission.scirp.org/

Or contact me@scirp.org 